Diabetologia $11,207-210(1975)$

(C) by Springer-Verlag 1975

\title{
The Enteral Insulin-Stimulation after Whipple's Operation
}

\author{
J. F. Rehfeld, F. Stadil, H. Baden and K. Fischerman \\ Dept. of Clinical Chemistry and Surgical Gastroenterology (F), Bispebjerg Hospital; Dept. of Surgical Gastroenterology (C), \\ Rigshospitalet; and Dept. of Surgical Gastroenterology (S), Gentofte Hospital, Hellerup, Denmark
}

Received: January 20, 1975, and in revised form: March 17, 1975

\begin{abstract}
Summary. The insulin response to oral and intravenous glucose was measured in ten patients after resection of antrum, duodenum, proximal jejunum, and the head of pancreas (Whipple's operation). Compared to matched normal subjects the operation reduced neither the total nor the gut hormone induced part of the insulin response to oral glucose.
\end{abstract}

The results suggest, that hormones from the first part of the intestinal tract are not necessary as incretins.

Key words: Gastrin, gastrointestinal hormones, glucose, incretin, insulin secretion, pancreatico-duodenectomy.
Oral ingestion of glucose in man causes an insulin response more than twice as big as that to parenteral glucose infusion $[4,6,7]$. This phenomenon has been attributed to an enteral factor called incretin [15], but the nature of incretin is still uncertain.

Hormones of the upper digestive tract - gastrin [2], cholecystokinin [2,5], secretin [2], and gastric inhibitory polypeptide (GIP) [3] - have all proved insulinogenic in high doses. Gastrin [10] and GIP [3] are moreover able to potentiate the glucose-induced insulin secretion in low doses that result in serum concentrations of the hormones that are within the physiological range. Gastrin and GIP may hence be considered proper incretins.

The aim of the present investigation was to evaluate whether the hormones produced in antrum, duodenum, and the oral part of jejunum actually are necessary as incretins. Patients having undergone Whipple's operation provide an opportunity to study this problem.

\section{Materials and Methods}

\section{Patients}

Ten patients were studied after Whipple's operation. The interval between operation and the investigation varied from one month to five years. Only patients without diabetic glucose tolerance were accepted in the study. Clinical data are summarized in the table. The patients were compared to ten normal individuals who were matched in respect to age, sex, weight, and height. Informed consent was obtained from all subjects. They were on a diet containing at least $250 \mathrm{~g}$ carbohydrate per day for three days before each test. After an overnight fast the examination began between $8: 00$ and 9:00 a.m.

\section{Experimental Procedure}

\section{Oral Glucose Tolerance Test}

The subjects were given $50 \mathrm{~g}$ glucose as a 25 per cent solution flavoured with lemon. Blood samples were collected from an canula inserted into an antecubital vein. The samples were drawn 10 and $5 \mathrm{~min}$ before glucose loading and 5, 10, 15, 20, 30, 40, 50, $60,90,120,150$, and $180 \mathrm{~min}$ after. Sera were stored at $-20^{\circ} \mathrm{C}$ until assayed.

\section{Intravenous Glucose Infusion Test}

One week after the oral test each subject was submitted to an intravenous glucose infusion test designed to immitate the changes in blood glucose concentrations measured during the oral glucose test: $16.7 \mathrm{~g}$ glucose in concentrations from 33 to $50 \%$, was given intravenously at a constant infusion rate. Termination of the infusion was aimed to coincide with the peak blood glucose concentration reached during the oral test in the same individual. The individual variation in time from start of the oral glucose test until peak blood glucose concentration was reached explains the variation in concentration of the glucose solution infused intravenously. Blood samples were drawn from the contralateral arm at the same intervals as those in the oral glucose test. The simple infusion test described here has been evaluated in detail elsewhere [12]. It is based on the observation that approximately one third of the glucose given orally escapes hepatic extraction in subjects with a normal glucose 
tolerance [7]. Although the intravenous glucose curve may not duplicate the oral glucose curve exactly in the single individual, the procedure has proved useful for groups of subjects with normal glucose tolerance [12].

\section{Laboratory Analysis}

Blood glucose concentrations were measured with a glucose oxidase method. Serum insulin and gastrin concentrations were measured radioimmunochemically. Detection limit, precision, accuracy, and specificity of the assays have been given in detail elsewhere [10]. The gastrin assay measures at least seven gastrin components of different molecular size in serum [11]; but the antiserum used in the present study binds all components with equimolar potency [13]. The sensitivity of the gastrin assay was in the present study, $5 \mathrm{pmol} / \mathrm{l}$ serum.

\section{Results}

The mean glucose concentrations during the oral and the intravenous glucose tests were identical in the first hour in the patients. During the next 1.5 hours the oral glucose concentrations were slightly above those of the intravenous test (Fig. 1). In the controls the oral and intravenous glucose curves were almost
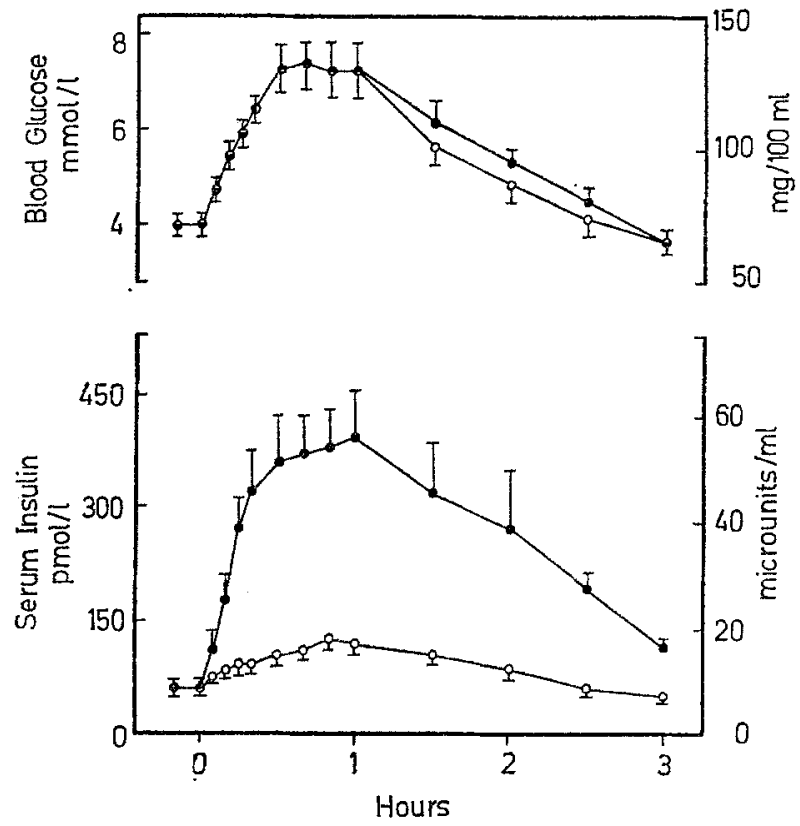

Fig. 1. Blood glucose and serum insulin concentrations during an oral glucose tolerance test (-) and an intravenous glucose infusion test $(0-0)$ in ten patients after Whipple's operation. The concentrations are shown as mean \pm standard error of mean identical during the whole test (Fig. 2), and the variations in blood glucose concentrations were of the same order of magnitude as observed in the patients.
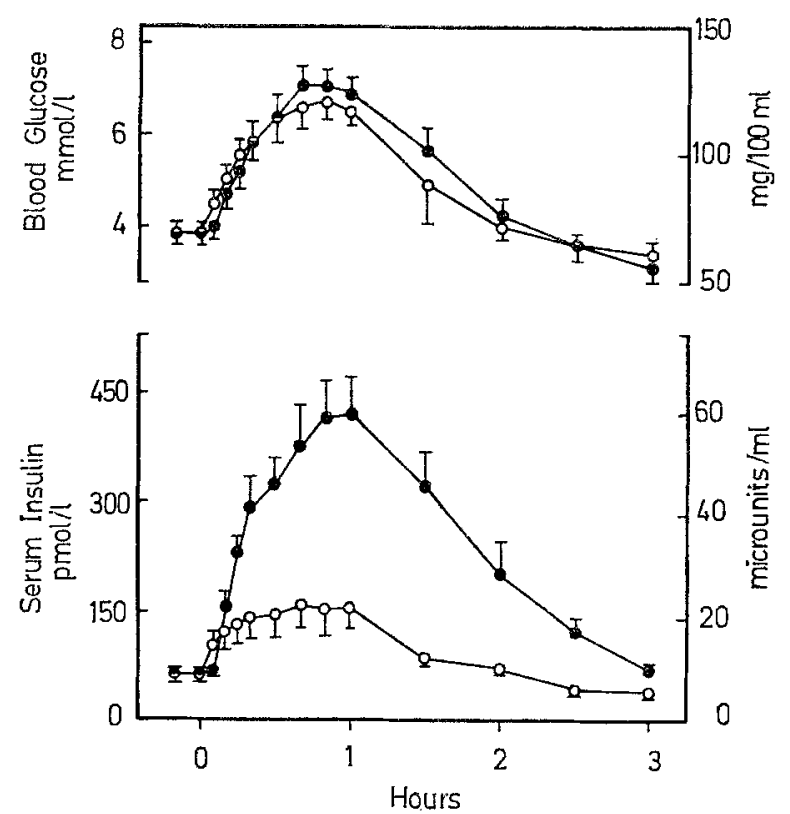

Fig. 2. Blood glucose and serum insulin concentrations during an oral glucose tolerance test (-C) and an intravenous glucose infusion test $\left(\mathrm{O}^{-} \mathrm{O}\right)$ in ten matched control subjects. The concentrations are shown as mean \pm standard error of mean

The insulin concentrations rose sharply in both patients and controls during the oral glucose test. The mean maximal insulin concentration was similar in patients and controls (Fig. 1 and 2). The higher insulin levels in the patients during the late part of the oral glucose test corresponds to the slightly higher glucose levels. During the first hour of the intravenous glucose infusion, the insulin concentrations were insignificantly lower in patients than in controls.

The gastrin concentrations in serum were low in all patients (Table 1 ), and in seven patients the concentrations were $0 \mathrm{pmol} / \mathrm{l}$ (i.e. below the detection limit of the assay). No significant changes in gastrin concentrations were observed during any of the glucose tests. Neither were insulin responses correlated to serum gastrin concentrations in any patient.

\section{Discussion}

The present study has shown that the insulin response to oral glucose is undiminished after resection of the upper parts of the gastrointestinal tract. Since blood glucose levels during the oral and the intravenous tests were normal and similar - in the first 
test-hour virtually identical - we conclude that hormones secreted from antrum, duodenum, and the first $10-15 \mathrm{~cm}$ of jejunum are not necessary for the insulin response to oral glucose. jejunum. In this context it is noteworthy that GIP, which recently has been suggested to constitute most or all of the incretin activity in man $[1,3]$ is produced "predominantly in duodenum and, to a lesser extent,

Table 1. Clinical data of ten patients undergoing Whipple's operation

\begin{tabular}{|c|c|c|c|c|c|c|}
\hline $\begin{array}{l}\text { Age } \\
\text { (yr) }\end{array}$ & Sex & $\begin{array}{l}\text { Height } \\
\text { (cm) }\end{array}$ & $\begin{array}{l}\text { Weight } \\
(\mathrm{kg})\end{array}$ & Diagnosis & $\begin{array}{l}\text { Resected } \\
\text { gut tissue }\end{array}$ & $\begin{array}{l}\text { Postoperative, } \\
\text { basal serum- } \\
\text { gastrin concen- } \\
\text { tration (pmol/l) }\end{array}$ \\
\hline 43 & $\mathbf{M}$ & 173 & 60 & $\begin{array}{l}\text { Carcinoma of } \\
\text { Papilla of Vater }\end{array}$ & $\begin{array}{l}\text { Antrum } \\
\text { Duodenum }\end{array}$ & 0 \\
\hline 46 & $\mathbf{M}$ & 170 & 60 & $\begin{array}{l}\text { Carcinoma of } \\
\text { Papilla of Vater }\end{array}$ & $\begin{array}{l}\text { Antrum } \\
\text { Duodenum } \\
10 \mathrm{~cm} \text { of jejunum }\end{array}$ & 10 \\
\hline 56 & $F$ & 162 & 51 & $\begin{array}{l}\text { Carcinoma of } \\
\text { Papilla of Vater }\end{array}$ & $\begin{array}{l}\text { Antrum } \\
\text { Duodenum } \\
10 \mathrm{~cm} \text { of jejunum }\end{array}$ & 12 \\
\hline 60 & M & 172 & 79 & $\begin{array}{l}\text { Carcinoma of } \\
\text { duodenum }\end{array}$ & $\begin{array}{l}\text { Antrum } \\
\text { Duodenum } \\
15 \mathrm{~cm} \text { of jejunum }\end{array}$ & 12 \\
\hline 61 & $\mathrm{~F}$ & 160 & 50 & $\begin{array}{l}\text { Carcinoma of } \\
\text { the head of } \\
\text { pancreas }\end{array}$ & $\begin{array}{l}\text { Antrum } \\
\text { Duodenum } \\
15 \mathrm{~cm} \text { of jejunum }\end{array}$ & 0 \\
\hline 64 & $\mathrm{~F}$ & 160 & 51 & $\begin{array}{l}\text { Carcinoma of } \\
\text { Papilla of Vater }\end{array}$ & $\begin{array}{l}\text { Antrum } \\
\text { Duodenum } \\
10 \mathrm{~cm} \text { of jejunum }\end{array}$ & 0 \\
\hline 65 & $\mathrm{~F}$ & 154 & 47 & $\begin{array}{l}\text { Carcinoma of } \\
\text { Papilla of Vater }\end{array}$ & $\begin{array}{l}\text { Antrum } \\
\text { Duodenum } \\
10 \mathrm{~cm} \text { of jejunum }\end{array}$ & 0 \\
\hline 66 & $M$ & 167 & 75 & $\begin{array}{l}\text { Carcinoma of } \\
\text { duodenum }\end{array}$ & $\begin{array}{l}\text { Antrum } \\
\text { Duodenum } \\
5 \mathrm{~cm} \text { of jejunum }\end{array}$ & 0 \\
\hline 75 & M & 181 & 74 & $\begin{array}{l}\text { Carcinoma of } \\
\text { the head of } \\
\text { pancreas }\end{array}$ & $\begin{array}{l}\text { Antrum } \\
\text { Duodenum } \\
10 \mathrm{~cm} \text { of jejunum }\end{array}$ & 0 \\
\hline 76 & $\mathbf{F}$ & 170 & 43 & $\begin{array}{l}\text { Carcinoma of } \\
\text { Papilla of Vater }\end{array}$ & $\begin{array}{l}\text { Antrum } \\
\text { Duodenum } \\
10 \mathrm{~cm} \text { of jejunum }\end{array}$ & 0 \\
\hline
\end{tabular}

The name incretin was introduced 35 years ago for a factor from duodenum, which stimulated the endocrine pancreas [15]. Its effect was demonstrated directly $[4,6]$ by reliable insulin assays ten years ago. In spite of great interest it has, however, not yet been possible to isolate one factor responsible for the whole insulin stimulating effect. On the contrary many different hormones of the upper digestive tract have now shown betacytotrophic actions [2, 3, 5]. Most studies with the gut hormones have been performed with pharmacological doses, but gastrin [10] and GIP [3] have now been administered in low amounts and proved able to potentiate the glucose-induced insulin secretion in "physiological" doses. As apparent from the present study, gastrin is, however, not required to obtain the incretin effect. The same applies for hormones secreted from duodenum and the first part of in the jejunum" [8]. Thus, although a minority of the GIP-producing cells are left after Whipple's operation, the results of the present study may question the wisdom of attributing the entire incretin effect to GIP.

Patients, in whom only the first $37 \mathrm{~cm}$ of jejunum and the last $13 \mathrm{~cm}$ of ileum are preserved in continuity, display well preserved incretin activity [9]. It consequently appears that there are two interpretations possible on the nature of incretin. It could be one or more hormones secreted from a short $20-30$ $\mathrm{cm}$ segment of the upper jejunum. This would be unique for an intestinal hormone. A more attractive possibility is therefore that all or a number of gut hormones interact to constitute the incretin effect. The incretin activity of the different hormones may vary according to the stimulus, so that the gastrin-family 
(gastrins and cholecystokinins) dominates during protein-rich meals, whereas the secretin-family (secretin, enteroglucagon, GIP, and Vasoactive Intestinal Polypeptide (VIP) and maybe yet unknown hormones from the jejunum) dominate during carbohydrate loadings.

When reliable assays for more gastrointestinal hormones are at hand, it may be worthwhile to restudy Whipple-operated patients in order to define the incretin activity more accurately. We have been able to draw conclusions only about gastrin, and as expected resection of the proximal gut reduced the circulating gastrin levels towards zero. It can thus be concluded that the amounts of gastrin, which might be secreted from the remaining jejunum and possibly from pancreas are negligible - as measured with the antiserum employed in the present study.

So far the incretin effect has been conceived as being of hormonal nature; but the possibility of neural influence via the vagus cannot be excluded. The question of neural control of insulin secretion was recently reviewed extensively [14]. Apparently no human studies have differentiated the direct effect of vagal stimulation of the pancreas from possible vagal stimulation of gastrointestinal hormones. However, since the enteral insulin-stimulation is well preserved in man after truncal vagotomy [Rehfeld, unpublished studies], we still regard incretin as constituted mainly by hormones from the digestive tract.

Acknowledgements. The technical assistance of Ulla Søegaard and Ninna Haack is gratefully acknowledged. The study was supported by grants from Landsforeningen til Kræftens Bekæmpelse, King Chr. X's Foundation, and the Danish Medical Research Council (j. nr. 512-1048 and 5122540).

\section{References}

1. Cataland, S., Crockett, S. E., Brown, J. C., Mazzaferri, E. L.: Gastric inhibitory polypeptide (GIP) stimulation by oral glucose in man. J. clin. Endocr. 39, 223-228 (1974)

2. Dupré, J., Curtis, J. D., Unger, R. H., Waddell, R. W., Beck, J.: Effects of secretin, pancreozymin, or gastrin on the response of the endocrine pancreas to administration of glucose or arginine in man. J. clin. Invest. 48, 745757 (1969)

3. Dupré, J., Ross, S., Watson, D., Brown, J. C.: Stimulation of insulin secretion by gastric inhibitory polypeptide in man. J. clin. Endocr. 37, 826-828 (1973)

4. Elrick, H., Stimmler, L., Hlad Jr., C. J., Arai, Y.: Plasma insulin response to oral and intravenous glucose administration. J. clin. Endocr. 24, 1076-1082 (1964)

5. Frame, C. M., Davidson, M. B., Sturdevant, R. A. L.: Effects of the octapeptide of cholecystokinin on insulin and glucagon secretion in the dog. Endocrinology, in press (1975)

6. McIntyre, N., Holdsworth, C. D., Turner, D. S.: New interpretation of oral glucose tolerance. Lancet 1964 II, 20-21

7. Perley, M. J., Kipnis, D. M.: Plasma insulin responses to oral and intravenous glucose: studies in normal and diabetic subjects. J. clin. Invest. 46, 1954-1962 (1967)

8. Polak, J. M., Bloom, S. R., Kuzio, M., Brown, J. C., Pearse, A. G. E: Cellular localization of gastric inhibitory poly-peptide in the duodenum and jejunum. Gut 14, 284-288 (1973)

9. Rehfeld, J. F., Juhl, E., Quaade, F.: Effect of jejunoileostomy on glucose and insulin metabolism in ten obese patients. Metabolism 19, 529-538 (1970)

10. Rehfeld, J. F., Stadil, F.: The effect of gastrin on basaland glucose-stimulated insulin secretion in man. J. clin. Invest. 52, 1415-1426 (1973)

11. Rehfeld, J. F., Stadil, F., Vikelsøe, J.: Immunoreactive gastrin components in human serum. Gut 15, 102-111 (1974)

12. Rehfeld, J. F., Stadil, F.: The glucose-induced gastro-intestinal stimulation of insulin secretion in man. Relation to age and gastrin secretion. Europ. J. clin. Invest. in press (1975)

13. Rehfeld, J. F., Stadil, F., Malmström, J., Miyata, M.: Gastrin heterogeneity in serum and tissue. In: Gastrointestinal Hormones (ed. J. C. Thompson). Austin: University of Texas Press. In press 1975

14. Woods, S. C., Porte Jr., D.: Neural control of the endocrine pancreas. Physiol. Rev. 54, 596-619 (1974)

15. Zunz, E., La Barre, J.: Contributions a l'étude des variations physiologiques de la sécretion interne du pancreas: rélations entre les sécretions externes et interne du pancreas. Arch. Intern. Physiol. 31, 20-44 (1929)

Dr. J .F. Rehfeld

Dept. of Clinical Chemistry

Bispebjerg Hospital

Bispebjerg Bakke 23

DK-2400 København NV

Denmark 